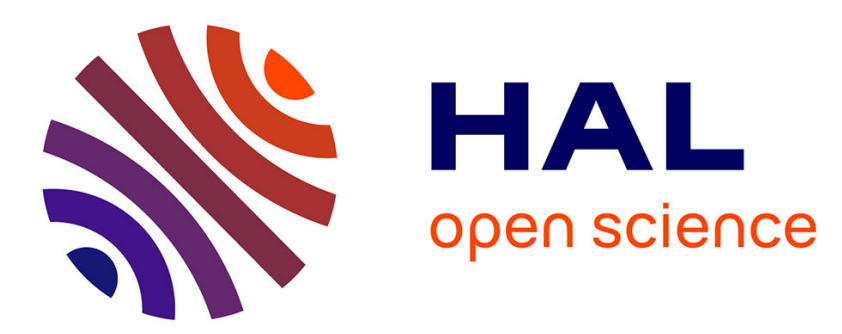

\title{
The Many Faces of Bacterium-Endothelium Interactions during Systemic Infections
}

Dorian Obino, Guillaume Duménil

\section{To cite this version:}

Dorian Obino, Guillaume Duménil. The Many Faces of Bacterium-Endothelium Interactions during Systemic Infections. Microbiology Spectrum, 2019, 7 (2), pp.69-81. 10.1128/microbiolspec.BAI-00102019 . pasteur-03100519

\section{HAL Id: pasteur-03100519 \\ https://hal-pasteur.archives-ouvertes.fr/pasteur-03100519}

Submitted on 15 Jan 2021

HAL is a multi-disciplinary open access archive for the deposit and dissemination of scientific research documents, whether they are published or not. The documents may come from teaching and research institutions in France or abroad, or from public or private research centers.
L'archive ouverte pluridisciplinaire HAL, est destinée au dépôt et à la diffusion de documents scientifiques de niveau recherche, publiés ou non, émanant des établissements d'enseignement et de recherche français ou étrangers, des laboratoires publics ou privés.

\section{(ㄷ)(1) $\$$}

Distributed under a Creative Commons Attribution - NonCommerciall 4.0 International 
0

\section{The many faces of bacterium-endothelium interactions during} systemic infections

(1)

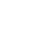

\author{
Dorian Obino and Guillaume Duménil*
}

\author{
Affiliation \\ Pathogenesis of Vascular Infections, Institut Pasteur, INSERM, Paris, France. \\ * Correspondence: guillaume.dumenil@pasteur.fr
}

\section{Abstract}

A wide variety of pathogens reach the blood circulation during viral, parasitic, fungal or bacterial infections, causing clinically diverse pathologies. Such systemic infections are usually particularly severe and frequently life-threatening despite intensive care, in particular at the age of antibiotic resistance. Because of its position at the interface between the blood and the rest of the organism, the endothelium plays a central role during these infections. Through several examples of systemic infections, we propose to explore the diversity of interactions between pathogens and the endothelium. These examples reveal that bacterial pathogens target specific vascular beds and affect most aspects of endothelial cell biology ranging from cellular junction stability to endothelial cell proliferation or inflammation. 


\section{THE ENDOTHELIUM AS A SITE OF BACTERIAL INFECTIONS}

The endothelium refers to the layer of endothelial cells (ECs) lining the inner surface of blood vessels that span the entire body and ensure the distribution of blood throughout the organism (1). It can be estimated that the human body contains the staggering number of $100000 \mathrm{~km}$ of blood vessels, more than twice the earth's circumference (2). Therefore, a bacterium reaching the circulation is engaged in a maze of huge proportion. Moreover, a pathogen travelling throughout the circulation does not encounter a homogeneous environment, as an important feature of the vascular network is its diversity. Although endothelial cells are present in all vessels, the organization of the vessel wall - formed by three layers referred to as the tunica intima, media and adventia (from the vessel lumen outward) - is different among different vessel types and different organs (3). Vessels can be first differentiated by the complex extracellular matrix layers surrounding them. For instance, elastic arteries such as the aorta are surrounded by 50 elastic layers providing them unique mechanical properties (3). Second, the cellular content is also different according to vessel type, the wall of arteries and veins contains a layer of smooth muscle cells (SMCs) that provides their capacity to relax or constrict in response to vasoactive molecules (4). An additional level of complexity in the network stems from the fact that larger vessels, veins or arteries are themselves vascularized by smaller vessels, the vasa vasorum (5). Although endothelial cells are constituent of all vessels, they themselves present different properties depending on their anatomical location, in particular in the case of capillaries. The lumen of continuous capillaries, which are the most common, are lined with an uninterrupted layer of endothelial cells. Fenestrated capillaries, typically present in glomeruli of the kidney, are laced with 50$80 \mathrm{~nm}$ openings thus changing their permeability properties. In the liver, sinusoidal 
capillaries contain numerous holes that can reach several microns in diameter and could in principle allow objects such as bacteria to escape the circulation (6). Also, particularly relevant to infection, sinusoidal capillaries host a large number of Küpffer cells, phagocytic cells that constantly filter the blood from particulate matter including bacteria (7). Finally, the heart, a central element of the circulation network and also a potential site of infection, displays a specialized endothelium referred to as the endocardium. In contrast to the endothelium, the endocardium is constituted of three juxtaposed layers that ensure i) its physical anchorage to the surface of the myocardium (the heart muscle), ii) its mechano-elastic properties allowing its adaptation to the heart contraction and relaxation cycles and iii) its low permeability thanks to a sealed monolayer of endothelial cells (8).

Although usually viewed as a static structure, the design of the blood vessel network is dynamic, in particular in the case of the smaller vessels, first during development but also following wound healing, cancer development, ischemia or infection $(9,10)$. During development, vasculogenesis supports the establishment of the arteries and the veins that transport the blood from and back to the heart, respectively (11). An additional mechanism, referred to as angiogenesis, gives rise to smaller vessels, such as blood capillaries of few micrometers in diameter, which deliver oxygen and nutrients to the body's tissues. These vessels elongate from endothelial sprouts emanating from pre-existing vessels and invade non-vascularized areas (12). Of note, capillaries are also able to interconnect through anastomosis, a process resulting in the fusion of two capillary growing-ends (13). Therefore, pathogens reaching the circulation encounter a complex, diverse and dynamic network. 


\section{CELLULAR JUNCTIONS AS THE GATEKEEPERS OF THE ENDOTHELIAL}

\section{BARRIER}

Through the fine control of vessel permeability, intercellular junctions within the endothelium are at the heart of the maintenance of vascular integrity, thus ensuring the proper barrier function of the endothelium (14). Among the two main types of endothelial cell-cell junctions, adherens junctions (AJ) are ubiquitously found, whereas tight junctions (TJ) are mainly located in endothelial barriers with a very high selectivity (15). This is the case of the blood-brain barrier, where tight junctions ensure the charge- and size-selective exchanges between the cerebral vasculature and the central nervous system (CNS) (16), thus participating in the protection of the brain parenchyma from bacterial invasion, for instance. The main component of adherens junctions is the intercellular adhesion molecule Vascular Endothelial (VE)Cadherin. VE-Cadherin proteins expressed at the surface of neighboring endothelial cells engage their extracellular domain within homotypic interactions that are stabilized by extracellular calcium (17), thus ensuring the sealing of the endothelium. Platelet-Endothelial Cell Adhesion Molecule (PECAM)-1 also participate in the structural integrity of AJs (18). Intracellularly, VE-Cadherin is linked to the actin cytoskeleton through its interactions with $\alpha-, \beta-, \gamma^{-}$and p120-Catenin (19) (Figure 1). In contrast, TJs are made by the homophilic interaction of cell adhesion molecules such as Claudins, Occludin and Junction Adhesion Molecules (JAMs), which are connected to the actin cytoskeleton through Zona Occludens (ZO)-1, -2 and -3 proteins (Figure 1). Because of their importance, the establishment and maintenance of cell-to-cell junctions are tightly controlled. One of the best illustrations of such regulation is the modulation of vessel permeability by the Vascular Endothelial Growth Factor (VEGF) $(20,21)$. Its binding to Vascular Endothelial Growth Factor 
97 Receptor (VEGFR)-2 induces an increase in intracellular calcium levels, leading to the subsequent activation of Src family kinases, MAP kinases, PI3 kinase and protein kinase $G(21,22)$. This mainly results in $i)$ the remodeling of the actin cytoskeleton, through the activation of the small GTPase Rho-A, ii) the activation of myosin lightchain kinase (MLCK) that favors actomyosin contractility, iii) the destabilization of integrin-mediated adhesion to the extracellular matrix and $i v$ ) the phosphorylation of VE-Cadherin and its internalization, thus loosening cell-cell junctions (23). All combined, these events participate in increasing endothelial permeability. In contrast, the activation of other small GTPases, such as Rac-1 or Cdc42, protect the barrier function of the endothelium by stabilizing intercellular junctions and the cortical actin cytoskeleton (24). Therefore, the fine regulation of the interface between intercellular junctions and the actin cytoskeleton plays a crucial role in regulating endothelial integrity.

Strikingly, certain pathogens have the ability to overcome the physical barrier imposed by the endothelium either from the outside towards the inside or/and vice versa to exit the vascular lumen and reach specific organs. Pathogenic bacteria can reach the circulation by accessing the vascular lumen through micro-abrasions within the skin or mucosa but also through insect bites (25-27). Once in the circulation, bacterial adhesion to the endothelium is a frequent starting point (28-30). Bacteria then either divert the host cell actin cytoskeleton to induce their internalization and transcytosis, leading to the passage of live bacteria through endothelial cells (31-35), or remain extracellular and interfere with the assembly of intercellular junctions facilitating their paracellular passage (36). 
121 Hence, bacterial interaction with the endothelium often leads to the alteration of

122 vascular integrity that might be at the origin of vascular leaks, bacterial dissemination

123 within the surrounding tissues and/or organ dysfunction.

124 Throughout different examples of infection, we will here illustrate the many faces of 125 bacteria-endothelium interactions and the subsequent perturbations of specific 126 vascular functions in the particular environment of the blood circulation.

127

128

129

130

131

\section{ALTERATION OF VASCULAR INTEGRITY UPON INFECTIONS BY RICKETTSIA}

Spotted fevers associated with rickettsial infections are among the best characterized examples of pathogenic bacteria with a vascular tropism and disturbing endothelial functions. Members of the Rickettsia family are obligate intracellular vector-borne pathogens mainly transmitted by tick bites and triggering diverse diseases such as typhus or spotted fever (27). Endothelial cells of the peripheral circulation represent the main target of Rickettsia belonging to the spotted fever group $(27,37,38)$ (Figure 2). Rickettsia adhesion to the endothelial surface is mediated by the expression of the outer-membrane protein (Omp)-A and B (39) and their interaction with endothelial integrins, such as the $\alpha_{2} \beta_{1}$ integrin (40). This induces a rapid and efficient internalization of the adherent bacteria within few minutes after the initial contact. Internalization occurs through a mechanism called "induced phagocytosis" that is at the crossroad between phagocytosis and endocytosis $(41,42)$ and involving Clathrin and Caveolin-2, two canonical proteins of the endocytic pathway (43).

Adhesion of Rickettsia onto endothelial cells also leads to a drastic remodeling of the actin cytoskeleton within the host cells that not only facilitates bacterial entry but also participates to bacteria movement and spreading within the endothelium. Endothelial cell surface-bond bacteria locally regulate actin rearrangements by recruiting the 
Arp2/3 complex and activating Cdc42 and kinases of the Src-family to support 147 bacterial internalization within phagosomal vesicles (44). The expression of the pore148 forming proteins Hemolysin C and Phospholipase D by Rickettsia allows them to escape phagosomes and access the host cell cytosol (45-47) where they benefit 150 from nutrients and energy present to support their growth (48). Within infected cells, 151 Rickettsia also uses proteins from the actin cytoskeleton to propel and disseminate 152 within adjacent endothelial cells. Rickettsia assembles polar actin tails made of 153 unbranched parallel actin filaments, which help intracellular bacterial movement (49).

154 The precise machinery allowing bacteria to assemble these actin comet tails remains debated. Whereas the involvement of RickA, a WASP-family protein homolog encoded by Rickettsia, in Arp2/3-mediated actin polymerization in vitro favors a mechanism of tail assembly relying on Arp2/3 activity $(50,51)$, Arp2/3 was not found to associate with Rickettsia actin tails $(52,53)$. An alternative hypothesis rather suggests that the bacterial protein Sca2 might participate in assembling actin tails through a formin-like mechanism $(54,55)$.

The infection of endothelial cells by Rickettsia leads to the activation of the endothelium, which is associated with the upregulation and secretion of a plethora of cytokines and chemokines, collectively referred to as rickettsial vasculitis (56). Interestingly, Rickettsia has developed different strategies to counteract immune responses and optimize their intracellular residence. First, Rickettsia has the ability to escape phagosomal vesicles before their fusion with lysosomes, hindering their degradation by the lysosomal content (47). Moreover, the bacterium activates the anti-apoptotic NF-kB signaling pathway within infected cells (57-60), thus balancing the killing of these cells mediated by the recruitment of CD8 T cells (61). 
170 Importantly, Rickettsia also damages the endothelium by altering the assembly of 171 endothelial intercellular junctions, most probably by disturbing the actin cytoskeleton

172 (62), as well as by inducing an oxidative stress within infected cells that contributes to

173

174

175

176

177

178

179

180

181

182

183 cell death $(63,64)$. Therefore, rickettsial infections lead to endothelial cell activation and dysfunction, including an alteration of the vascular integrity that results in the increase in vascular permeability and concurring to the pathophysiology of Rickettsiainduced vascular leaks $(56,65)$. Despite alterations in vascular integrity, rickettsial infections are not associated with subsequent dissemination to other organs, such as the brain as in the case of meningitis-causing pathogens.

\section{VASCULAR COLONIZATION AND BLOOD-BRAIN BARRIER CROSSING BY}

\section{NEISSERIA MENINGITIDIS}

A limited number of pathogenic bacteria have developed mechanisms allowing them to cross the blood-brain barrier (BBB), most often triggering bacterial meningitis, a high-fatality rate disease (66). A hallmark feature of the clinical manifestations of bacterial meningitis is the presence of the pathogenic bacterium within the cerebrospinal fluid (CSF) where it triggers the inflammation of the meninges and the recruitment of immune cells within the $\operatorname{CSF}(66,67)$. Since the bacterium is also found in the bloodstream, the most prevalent view is that the bacterium breaches the blood-CSF barrier to reach the CSF. However, as at this stage the anatomical site at which crossing occurs is not known, we will rather refer to crossing of the blood-brain barrier to be more inclusive.

With significant socioeconomic and geographic variations, Neisseria meningitidis, Streptococcus pneumoniae and type B Haemophilus influenzae are the most frequent causative agents of bacterial meningitis in adults and children. Of note, 
195 while neonatal meningitis is mainly triggered by group B Streptococcus, Listeria 196 monocytogenes and Escherichia coli K1 (68), immunocompromised patients 197 frequently developed Mycobacterium tuberculosis or non-typhoid Salmonella 198 meningitis $(69,70)$. Despite their heterogeneity, common themes in the mechanisms 199 used by these pathogenic bacteria to cross the BBB can be drawn (for review, see $200(71))$.

201 Recent studies have pointed to the importance of a process called vascular 202 colonization during N. meningitidis infections and probably during meningitis (72). 203 This bacterium has the ability to adhere to the endothelial surface and proliferate in 204 the form of bacterial aggregates that eventually fill the lumen of small vessels of 10 to $20550 \mu \mathrm{m}$ in diameter (Figure 3 ). A recent study shows that this colonization process is 206 facilitated by the honey-like viscous liquid properties of the bacterial aggregates 207 which allow them to adapt to the complex morphology of the vasculature upon 208 proliferation (73). Adhesion to the endothelium likely participates in the immune evasion as this prevents phagocytosis from Küpffer cells in the liver. Histological 210 analysis of post-mortem samples reveals large bacterial aggregates in the brain 211 vessels suggesting that vascular colonization could promote BBB crossing by concentrating a high number of bacteria at specific sites and by altering endothelial cell physiology (74). The combined effect of vessel occlusion due to bacterial 214 accumulation and the activation of the coagulation cascade (75) might participate in 215 altering endothelium integrity.

216 Alternatively, in vitro studies have identified specific signaling pathways triggered by $217 N$. meningitidis, which lead to the opening of intercellular junctions within the cerebral endothelium. Meningococcal adhesion to the host cells is mediated by their expression of type four pili (Tfp) (76) that engage host cell surface receptors, such as 
220 CD147 and $\beta 2$-adrenergic receptor $(77,78)$. While proliferating at the surface of

221 infected endothelial cells, thus forming bacterial aggregates, meningococci induce

222 the remodeling of the host cell plasma membrane $(79,80)$ (Figure 3 ). Associated to

223 their aggregation capacity, plasma membrane protrusions infiltrating meningococcal

224 microcolonies were shown to enhance the mechanical cohesion of the microcolony

225 thus allowing them to resist the blood-flow induced shear stress (81). Interestingly,

226 although the cortical actin network is strongly reorganized below the bacterial

227 colonies (82), the active contribution of the host cells has been shown to be

228 dispensable in the $\mathrm{Nm}$-mediated plasma membrane remodeling. The actin

229 cytoskeleton or even the intracellular ATP is not necessary for the Tfp-induced 230 plasma membrane reorganization $(80,81)$. Upon bacterial adhesion to microvascular 231 endothelial cells, Tfp trigger a complex cascade of signaling events leading to the 232 formation of "ectopic junctions" underneath bacterial aggregates together with the 233 local remodeling of the cortical actin cytoskeleton (83). This process relies, on the 234 one hand, on the activation of small GTPases such as cell division cycle protein 42 235 (Cdc42) and Rac1, along with the local recruitment of proteins of the polarity 236 complex, including partitioning-defective 3 (PAR3), PAR6 and protein kinase $C-\zeta$ 237 (PKC- $-\xi)$, as well as the branched-actin nucleating complex Arp2/3. On the other 238 hand, by mistargeting recycling endosomes, meningococci induce the accumulation 239 of junctional proteins, such as VE-Cadherin, underneath bacterial aggregates, a 240 process shown to weaken intercellular junctions and increase blood-brain barrier 241 permeability, thus facilitating meningococcal dissemination within the cerebral tissues 242 and the cerebrospinal fluid (CSF) (83). These elaborated mechanisms illustrate the panoply of strategies enabling pathogenic bacteria to alter the endothelial barrier. 


\section{ALTERATION OF THE ENDOCARDIUM AND ENDOCARDITIS}

246 Infective endocarditis (IE) is a bacterial infection of the cardiac endothelium. The

247 hallmark of IE is the colonization and destruction of the cardiac valves by pathogenic 248 bacteria following local endothelial injury or inflammation $(84,85)$ (for review, see 249 (86)). Although the causative agent of such a disease greatly varies according to the 250 geographic zones, most IE result from Staphylococcus aureus, Enteroccocus or 251 Streptococcus species, among which S. gallolyticus $(87,88)$.

252 The pathologic cascade starts following sterile lesions of the cardiac valve 253 endothelium of unclear origin that lead to the exposure of the extracellular matrix. 254 This triggers the formation of a platelet- and fibrin-rich thrombus, considered as a 255 hot-spot for the adhesion of blood-circulating bacteria (89) (Figure 4). Alternatively, 256 bacterial adhesion can occur at the surface of inflamed endothelium, a process 257 facilitated by the local upregulation of cell surface adhesion molecules, such as $\beta 1$ 258 integrins (90). From the bacterial side, adhesion is mediated by the surface 259 expression of extracellular matrix-targeting adhesins, such as fibronectin binding 260 proteins (FnBPs) $(91,92)$. Adherent bacteria locally proliferate and form a vegetation, 261 a biofilm-like structure where aggregated bacteria are mixed together with 262 extracellular matrix proteins, clot components and/or immune cells (93). While the 263 vegetation matures, the adjacent endothelial cells are exposed, thus driving the 264 propagation of the local inflammation and cell death and ultimately leading to the 265 destruction of the infected valves thus requiring surgical replacement (94). However, 266 this mechanism probably does not entirely account for IE induced by intracellular 267 bacteria such as Bartonella species or Staphylococcus aureus, which rather rely on 268 the secretion of exoenzymes and toxins to mediate their pathogenic effects (95) and 269 for which the host immune response might play an important role (96). Although 
Bartonella species have been described in relatively rare cases of human endocarditis $(97,98)$ with a preferential localization at the aortic valve $(99)$, these bacteria are mostly known for their involvement in angioproliferative syndromes.

\section{ANGIOPROLIFERATION DURING BARTONELLA INFECTIONS}

As mentioned earlier, angiogenesis supports the formation of new blood vessels from pre-existing ones (12). Interestingly, this process can be diverted by pathogenic bacteria and especially Bartonella henselae (for review, see (100)). Bartonella spp. are Gram-negative organisms found in domestic and wild mammals with a tropism for red blood cells and endothelial cells $(100,101)$. While in healthy individuals, Bartonella henselae infections cause benign cat scratch diseases (102), in immunocompromised patients these infections can trigger a vasoproliferative syndrome resulting in the formation of tumor-like nodules in the skin, known as cutaneous bacillary angiomatosis (BA) (100). This results from the ability of Bartonella henselae to invade endothelial cells and trigger their proliferation and migration $(103,104)$ together with the recruitment of macrophages, monocytes and polymorphonuclear neutrophils $(105,106)$ (Figure 5).

Interestingly, similar to Neisseria meningitidis microcolonies, $B$. henselae also forms plasma membrane-associated bacterial aggregates that either remain at the surface of or are internalized in infected endothelial cells (106). Two actin-dependent mechanisms have been described regarding bacterial internalization within endothelial cells $(107,108)$ : the first one is reminiscent of the previously described bacterium-induced phagocytosis and allows the relatively fast entry of Bartonella within perinuclear phagosomes (109). The second mechanism, lasting for up to 24 hours, allows the slow internalization of small $B$. henselae aggregates within large 
295 vacuoles, referred to as invasomes (107). Of note, similarly to the protective 296 mechanisms developed by Rickettsia to promote their survival during their 297 intracellular residence, Bartonella is able to inhibit key steps of the apoptosis 298 program induced upon cell infections (110).

299 Although not fully understood, the proliferation of infected endothelial cells is in part 300 supported by bacterial proteins that are translocated within the host cells through the 301 VirB-VirD4 type IV secretion system (T4SS) encoded by Bartonella $(111,112)$. In 302 addition, several reports have shown that macrophages, locally recruited upon endothelial cell infection, participate in the pathological angiogenesis induced by

Bartonella. Indeed, macrophages are well-known producers of pro-angiogenic factors upon activation (113). In vitro, macrophages have been shown to support endothelial proliferation through the secretion of VEGF in response to $B$. henselae infection (114, 115), thus suggesting that macrophages are involved in a paracrine loop that enhances Bartonella-mediated vasoproliferation (116).

\section{SYSTEMIC IMPLICATIONS OF VASCULAR INFECTIONS}

Under steady-state conditions, besides normal transitory bacteremia, the vascular organ is thought to be sterile (26). Therefore, it possesses robust mechanisms to recognize circulating pathogens and trigger innate and/or adaptive immune responses $(117,118)$. Similarly to immune cells specialized in pathogen recognition, endothelial cells express chemokine receptors, such as CXCR-1, -2 and -4 (119, 120) as well as pattern-recognition receptors (PRRs), such as Toll-Like Receptors (TLRs) and NOD-Like Receptors (NLRs) $(121,122)$. They have also been shown to secrete pro-inflammatory molecules, such as the cytokines interleukin (IL)-1 and -8 (123-125) and to respond to bacterial lipopolysaccharide (LPS), tumor necrosis 
320 factor- $\alpha$ (TNF- $\alpha)$ or interferon- $\gamma($ INF- $\gamma)$ by signaling through the canonical pro-

321 inflammatory NF-кB pathway (126). Hence, the endothelium possesses an array of 322 tools allowing the recognition of pathogenic microorganisms and the recruitment of 323 cells from the innate immune system in order to clear blood-circulating pathogens.

324 Of particular interest, endothelial cells (ECs) also participate in mounting adaptive 325 immune responses since they can act as antigen presenting cells (APCs) (127). The 326 hallmark of APCs is their expression of major histocompatibility complex class II 327 (MHC-II) molecules allowing them to present extracellular antigens to T cells (128). 328 Whereas quiescent ECs express basal levels of MHC-II molecules (129), they 329 possess the capacity to upregulate their expression upon activation (130), providing 330 them with the ability to present antigenic determinants to $T$ cells and rapidly initiate 331 pathogen-specific immune responses. Therefore, endothelial cells are equipped to 332 recognize pathogenic microorganisms, locally attract cells of the innate immunity and 333 serve as a link to trigger adaptive immune responses in order to efficiently fight 334 invaders (for review, see (131)).

335 Although invasion of the endothelium by bacteria leads to the activation of the 336 immune system, in absence of appropriate treatments or when the body fails clearing 337 the pathogens, it might evolve toward an uncontrolled and systemic affection. Indeed, 338 the constant release of damage-associated molecular patterns (DAMPs) by invading bacteria and/or injured endothelium leads to the imbalance of various body systems, 340 among which the overstimulation of immune cells through TLRs and the complement 341 pathway (132), as well as the exacerbated production of cytokines, referred to as the 342 cytokine storm (133). Together with a persistent bacteremia, this systemic 343 inflammatory response syndrome (SIRS) is the hallmark of sepsis $(134,135)$. 
344 Paradoxically, a common feature of sepsis is its association with a form of immune 345 suppression occurring after the unregulated inflammation $(132,136)$. While not fully 346 understood, sepsis is marked by the severe depletion of T and B cells, as well as 347 dendritic cells, which all show an enhanced pro-apoptotic activity $(137,138)$. In 348 addition, in patients suffering from sepsis, a bias in the ratio of regulatory over 349 effector T cells is often observed $(138,139)$. The latter also showing a reduced ability 350 to produce cytokines, a feature known as T cell exhaustion (140), most probably due 351 to dysregulations in the programmed cell death 1 (PD1) - PD1 ligand 1 (PDL1) axis 352 (141), owing to the exacerbated cytokine production.

353 In addition, sepsis frequently affects the coagulation pathway: ranging from the 354 formation of small thrombi to the manifestation of disseminated intravascular 355 coagulation (DIC) -which corresponds to the coagulation of the blood throughout the 356 entire body- coagulopathies are one of the major complications in sepsis and have been extensively reviewed elsewhere $(142,143)$. Nevertheless, we would like to 358 mention that perturbation of the coagulation pathway occurs early during sepsis and 359 first results from the activation of the endothelium in response to the cytokine storm, 360 thus favoring the local deposition of fibrin at the surface of the vessel walls (133).

361 Alternatively, endotoxins derived from Gram-negative bacteria, such as the 362 lipopolysaccharide (LPS), can trigger in a NF-kB-dependent manner both the 363 secretion and the surface expression of tissue factor (TF) by endothelial cells and 364 circulatory blood cells. By making a complex with the activated coagulation factor VII 365 (FVIIa), TF is a highly potent pro-coagulant molecule $(144,145)$. In both scenarios, 366 thrombus formation in turn leads to the activation of the endothelial cell surface 367 protease-activated receptor (PAR)-1 that signals through the small GTPase RhoA to 368 disassemble actin filaments and induce VE-Cadherin internalization, hence affecting 
369 the stability of intercellular junctions and the integrity of the vascular endothelium 370 (118). As a consequence, vessels become leaky, blood pressure decreases and 371 proteins from the endothelial extracellular matrix, such as collagen, are exposed to

372 the vessel content, which further activates platelet aggregation and fibrin formation $373(118,143)$. Multi-organ failure is often associated with the late phases of DIC, which 374 results from microvascular thrombosis and poor tissue perfusion $(146,147)$.

\section{CONCLUDING REMARKS}

377 Bacterial infections taking place in the circulation are particularly problematic because of the specific alterations they cause to the circulation, possibly affecting the entire body. According to the specific site of infection and the properties of the different pathogens, a complex set of interactions takes place during these infections. Blood vessels are highly diverse with broad ranges of size and structure and each pathogen has a set of virulence factors that alter blood vessel function in specific ways. As a result, clinical manifestations are also very different. However, despite this diversity, the endothelium is at the center of these infectious processes and a limited number of endothelial functions are targeted in these infectious contexts: the integrity of the vasculature and its permeability, but also its inflammatory and coagulation status. More research is needed on host-pathogen interactions during these systemic infections and on endothelial cell biology to better treat these 389 infections. 


\section{Acknowledgments}

395 The authors acknowledge Daria Bonazzi and Paul Kennouche for the critical reading 396 of the manuscript. DO was supported by a Pasteur-Roux postdoctoral fellowship from

397 the Institut Pasteur. Funding was obtained from the European Research Council 398 (ERC VIP consolidator grant) and the Integrative Biology of Emerging Infectious 399 Diseases (IBEID) laboratory of excellence (ANR-10-LABX-62) to GD. 
401 1. Lerman A, Burnett JC, Jr. 1992. Intact and altered endothelium in regulation

2. Sender R, Fuchs S, Milo R. 2016. Revised Estimates for the Number of Human and Bacteria Cells in the Body. PLoS Biol 14:e1002533.

3. Pugsley MK, Tabrizchi R. 2000. The vascular system. An overview of structure and function. J Pharmacol Toxicol Methods 44:333-340.

4. Brozovich FV, Nicholson CJ, Degen CV, Gao YZ, Aggarwal M, Morgan KG. 2016. Mechanisms of Vascular Smooth Muscle Contraction and the Basis for Pharmacologic Treatment of Smooth Muscle Disorders. Pharmacol Rev 68:476-532.

5. Galili O, Herrmann J, Woodrum J, Sattler KJ, Lerman LO, Lerman A. 2004. Adventitial vasa vasorum heterogeneity among different vascular beds. J Vasc Surg 40:529-535.

6. Sarin H. 2010. Physiologic upper limits of pore size of different blood capillary types and another perspective on the dual pore theory of microvascular permeability. J Angiogenes Res 2:14.

7. Bilzer M, Roggel F, Gerbes AL. 2006. Role of Kupffer cells in host defense and liver disease. Liver Int 26:1175-1186.

8. Harris IS, Black BL. 2010. Development of the endocardium. Pediatr Cardiol 31:391-399.

9. Carmeliet P. 2003. Angiogenesis in health and disease. Nat Med 9:653-660.

10. Zecchin A, Kalucka J, Dubois C, Carmeliet P. 2017. How Endothelial Cells Adapt Their Metabolism to Form Vessels in Tumors. Front Immunol 8:1750.

11. Risau W, Flamme I. 1995. Vasculogenesis. Annu Rev Cell Dev Biol 11:73-91.

12. Risau W. 1997. Mechanisms of angiogenesis. Nature 386:671-674.

13. Diaz-Santana A, Shan M, Stroock AD. 2015. Endothelial cell dynamics during anastomosis in vitro. Integr Biol (Camb) 7:454-466.

14. Komarova Y, Malik AB. 2010. Regulation of endothelial permeability via paracellular and transcellular transport pathways. Annu Rev Physiol 72:463493.

15. Hawkins BT, Davis TP. 2005. The blood-brain barrier/neurovascular unit in health and disease. Pharmacol Rev 57:173-185.

16. Daneman R, Prat A. 2015. The blood-brain barrier. Cold Spring Harb Perspect Biol 7:a020412.

17. Rudini N, Dejana E. 2008. Adherens junctions. Curr Biol 18:R1080-1082.

18. Privratsky JR, Newman PJ. 2014. PECAM-1: regulator of endothelial junctional integrity. Cell Tissue Res 355:607-619.

19. Hartsock A, Nelson WJ. 2008. Adherens and tight junctions: structure, function and connections to the actin cytoskeleton. Biochim Biophys Acta 1778:660-669.

20. Bates DO, Harper SJ. 2002. Regulation of vascular permeability by vascular endothelial growth factors. Vascul Pharmacol 39:225-237.

21. Bates DO. 2010. Vascular endothelial growth factors and vascular permeability. Cardiovasc Res 87:262-271.

22. Wu HM, Huang Q, Yuan Y, Granger HJ. 1996. VEGF induces NO-dependent hyperpermeability in coronary venules. Am J Physiol 271:H2735-2739. 
23. Aghajanian A, Wittchen ES, Allingham MJ, Garrett TA, Burridge K. 2008. Endothelial cell junctions and the regulation of vascular permeability and leukocyte transmigration. J Thromb Haemost 6:1453-1460.

24. Popoff MR, Geny B. 2009. Multifaceted role of Rho, Rac, Cdc42 and Ras in intercellular junctions, lessons from toxins. Biochim Biophys Acta 1788:797812.

25. Round H, Kirkpatrick HJ, Hails CG. 1936. Further Investigations on Bacteriological Infections of the Mouth: (Section of Odontology). Proc $R$ Soc Med 29:1552-1556.

26. Cobe HM. 1954. Transitory bacteremia. Oral Surg Oral Med Oral Pathol 7:609-615.

27. Snowden J, Bhimji SS. 2018. Rickettsial Infection, StatPearls, Treasure Island (FL).

28. Stins MF, Prasadarao NV, Ibric L, Wass CA, Luckett P, Kim KS. 1994. Binding characteristics of $S$ fimbriated Escherichia coli to isolated brain microvascular endothelial cells. Am J Pathol 145:1228-1236.

29. Greiffenberg L, Goebel W, Kim KS, Weiglein I, Bubert A, Engelbrecht F, Stins M, Kuhn M. 1998. Interaction of Listeria monocytogenes with human brain microvascular endothelial cells: InIB-dependent invasion, long-term intracellular growth, and spread from macrophages to endothelial cells. Infect Immun 66:5260-5267.

30. Sheen TR, Ebrahimi CM, Hiemstra IH, Barlow SB, Peschel A, Doran KS. 2010. Penetration of the blood-brain barrier by Staphylococcus aureus: contribution of membrane-anchored lipoteichoic acid. $J \mathrm{Mol}$ Med (Berl) 88:633-639.

31. Stins MF, Badger J, Sik Kim K. 2001. Bacterial invasion and transcytosis in transfected human brain microvascular endothelial cells. Microb Pathog 30:19-28.

32. Jain SK, Paul-Satyaseela M, Lamichhane G, Kim KS, Bishai WR. 2006. Mycobacterium tuberculosis invasion and traversal across an in vitro human blood-brain barrier as a pathogenic mechanism for central nervous system tuberculosis. J Infect Dis 193:1287-1295.

33. Nikulin J, Panzner U, Frosch M, Schubert-Unkmeir A. 2006. Intracellular survival and replication of Neisseria meningitidis in human brain microvascular endothelial cells. Int J Med Microbiol 296:553-558.

34. Prasadarao NV, Wass CA, Stins MF, Shimada H, Kim KS. 1999. Outer membrane protein A-promoted actin condensation of brain microvascular endothelial cells is required for Escherichia coli invasion. Infect Immun 67:5775-5783.

35. Das A, Asatryan L, Reddy MA, Wass CA, Stins MF, Joshi S, Bonventre JV, Kim KS. 2001. Differential role of cytosolic phospholipase A2 in the invasion of brain microvascular endothelial cells by Escherichia coli and Listeria monocytogenes. J Infect Dis 184:732-737.

36. Dumenil G. 2011. Revisiting the extracellular lifestyle. Cell Microbiol 13:11141121.

37. Olano JP. 2005. Rickettsial infections. Ann N Y Acad Sci 1063:187-196.

38. Walker DH, Ismail $\mathbf{N}$. 2008. Emerging and re-emerging rickettsioses: endothelial cell infection and early disease events. Nat Rev Microbiol 6:375386. 
503

504

505

506

507

508

509

510

511

512

513

514

515

516

517

518

519

520

521

522

523

524

525

526

527

528

529

530

531

532

533

534

535

536

537

538

539

540

541

542

543

544

545

39. Li H, Walker DH. 1998. rOmpA is a critical protein for the adhesion of Rickettsia rickettsii to host cells. Microb Pathog 24:289-298.

40. Hillman RD, Jr., Baktash YM, Martinez JJ. 2013. OmpA-mediated rickettsial adherence to and invasion of human endothelial cells is dependent upon interaction with alpha2beta1 integrin. Cell Microbiol 15:727-741.

41. Walker TS, Winkler HH. 1978. Penetration of cultured mouse fibroblasts (L cells) by Rickettsia prowazeki. Infect Immun 22:200-208.

42. Walker TS. 1984. Rickettsial interactions with human endothelial cells in vitro: adherence and entry. Infect Immun 44:205-210.

43. Chan YG, Cardwell MM, Hermanas TM, Uchiyama T, Martinez JJ. 2009. Rickettsial outer-membrane protein $\mathrm{B}(\mathrm{rOmpB})$ mediates bacterial invasion through Ku70 in an actin, c-Cbl, clathrin and caveolin 2-dependent manner. Cell Microbiol 11:629-644.

44. Martinez JJ, Cossart P. 2004. Early signaling events involved in the entry of Rickettsia conorii into mammalian cells. J Cell Sci 117:5097-5106.

45. Radulovic S, Troyer JM, Beier MS, Lau AO, Azad AF. 1999. Identification and molecular analysis of the gene encoding Rickettsia typhi hemolysin. Infect Immun 67:6104-6108.

46. Renesto P, Dehoux P, Gouin E, Touqui L, Cossart P, Raoult D. 2003. Identification and characterization of a phospholipase D-superfamily gene in rickettsiae. J Infect Dis 188:1276-1283.

47. Whitworth T, Popov VL, Yu XJ, Walker DH, Bouyer DH. 2005. Expression of the Rickettsia prowazekii pld or tlyC gene in Salmonella enterica serovar Typhimurium mediates phagosomal escape. Infect Immun 73:6668-6673.

48. Walker DH, Valbuena GA, Olano JP. 2003. Pathogenic mechanisms of diseases caused by Rickettsia. Ann N Y Acad Sci 990:1-11.

49. Heinzen RA. 2003. Rickettsial actin-based motility: behavior and involvement of cytoskeletal regulators. Ann N Y Acad Sci 990:535-547.

50. Jeng RL, Goley ED, D'Alessio JA, Chaga OY, Svitkina TM, Borisy GG, Heinzen RA, Welch MD. 2004. A Rickettsia WASP-like protein activates the Arp2/3 complex and mediates actin-based motility. Cell Microbiol 6:761-769.

51. Gouin E, Egile C, Dehoux P, Villiers V, Adams J, Gertler F, Li R, Cossart P. 2004. The RickA protein of Rickettsia conorii activates the Arp2/3 complex. Nature 427:457-461.

52. Gouin E, Gantelet H, Egile C, Lasa I, Ohayon H, Villiers V, Gounon P, Sansonetti PJ, Cossart P. 1999. A comparative study of the actin-based motilities of the pathogenic bacteria Listeria monocytogenes, Shigella flexneri and Rickettsia conorii. J Cell Sci 112 ( Pt 11):1697-1708.

53. Harlander RS, Way M, Ren Q, Howe D, Grieshaber SS, Heinzen RA. 2003. Effects of ectopically expressed neuronal Wiskott-Aldrich syndrome protein domains on Rickettsia rickettsii actin-based motility. Infect Immun 71:15511556.

54. Haglund CM, Choe JE, Skau CT, Kovar DR, Welch MD. 2010. Rickettsia Sca2 is a bacterial formin-like mediator of actin-based motility. Nat Cell Biol 12:1057-1063.

55. Kleba B, Clark TR, Lutter El, Ellison DW, Hackstadt T. 2010. Disruption of the Rickettsia rickettsii Sca2 autotransporter inhibits actin-based motility. Infect Immun 78:2240-2247.

56. Sahni SK, Narra HP, Sahni A, Walker DH. 2013. Recent molecular insights into rickettsial pathogenesis and immunity. Future Microbiol 8:1265-1288. 
57. Sporn LA, Sahni SK, Lerner NB, Marder VJ, Silverman DJ, Turpin LC, Schwab AL. 1997. Rickettsia rickettsii infection of cultured human endothelial cells induces NF-kappaB activation. Infect Immun 65:2786-2791.

58. Sahni SK, Van Antwerp DJ, Eremeeva ME, Silverman DJ, Marder VJ, Sporn LA. 1998. Proteasome-independent activation of nuclear factor kappaB in cytoplasmic extracts from human endothelial cells by Rickettsia rickettsii. Infect Immun 66:1827-1833.

59. Clifton DR, Goss RA, Sahni SK, van Antwerp D, Baggs RB, Marder VJ, Silverman DJ, Sporn LA. 1998. NF-kappa B-dependent inhibition of apoptosis is essential for host cellsurvival during Rickettsia rickettsii infection. Proc Natl Acad Sci U S A 95:4646-4651.

60. Walker DH. 2007. Rickettsiae and rickettsial infections: the current state of knowledge. Clin Infect Dis 45 Suppl 1:S39-44.

61. Walker DH, Olano JP, Feng HM. 2001. Critical role of cytotoxic T lymphocytes in immune clearance of rickettsial infection. Infect Immun 69:1841-1846.

62. Valbuena G, Walker DH. 2005. Changes in the adherens junctions of human endothelial cells infected with spotted fever group rickettsiae. Virchows Arch 446:379-382.

63. Santucci LA, Gutierrez PL, Silverman DJ. 1992. Rickettsia rickettsii induces superoxide radical and superoxide dismutase in human endothelial cells. Infect Immun 60:5113-5118.

64. Eremeeva ME, Silverman DJ. 1998. Effects of the antioxidant alpha-lipoic acid on human umbilical vein endothelial cells infected with Rickettsia rickettsii. Infect Immun 66:2290-2299.

65. Schmaier AH, Srikanth S, Elghetany MT, Normolle D, Gokhale S, Feng HM, Walker DH. 2001. Hemostatic/fibrinolytic protein changes in $\mathrm{C} 3 \mathrm{H} / \mathrm{HeN}$ mice infected with Rickettsia conorii--a model for Rocky Mountain spotted fever. Thromb Haemost 86:871-879.

66. Doran KS, Fulde M, Gratz N, Kim BJ, Nau R, Prasadarao N, SchubertUnkmeir A, Tuomanen El, Valentin-Weigand P. 2016. Host-pathogen interactions in bacterial meningitis. Acta Neuropathol 131:185-209.

67. Brandtzaeg P, van Deuren M. 2012. Classification and pathogenesis of meningococcal infections. Methods Mol Biol 799:21-35.

68. Thigpen MC, Whitney CG, Messonnier NE, Zell ER, Lynfield R, Hadler JL, Harrison LH, Farley MM, Reingold A, Bennett NM, Craig AS, Schaffner W, Thomas A, Lewis MM, Scallan E, Schuchat A, Emerging Infections Programs N. 2011. Bacterial meningitis in the United States, 1998-2007. N Engl J Med 364:2016-2025.

69. Bekondi C, Bernede C, Passone N, Minssart P, Kamalo C, Mbolidi D, Germani Y. 2006. Primary and opportunistic pathogens associated with meningitis in adults in Bangui, Central African Republic, in relation to human immunodeficiency virus serostatus. Int J Infect Dis 10:387-395.

70. Fernandez Guerrero ML, Ramos JM, Nunez A, Cuenca M, de Gorgolas M. 1997. Focal infections due to non-typhi Salmonella in patients with AIDS: report of 10 cases and review. Clin Infect Dis 25:690-697.

71. van Sorge NM, Doran KS. 2012. Defense at the border: the blood-brain barrier versus bacterial foreigners. Future Microbiol 7:383-394.

72. Melican K, Michea Veloso P, Martin T, Bruneval P, Dumenil G. 2013. Adhesion of Neisseria meningitidis to dermal vessels leads to local vascular 
603

604

605

606

607

608

609

610

611

612

613

614

615

616

617

618

619

620

621

622

623

624

625

626

627

628

629

630

631

632

633

634

635

636

637

638

639

640

641

642

643

644

645

damage and purpura in a humanized mouse model. PLoS Pathog 9:e1003139.

73. Bonazzi D, Lo Schiavo V, Machata S, Djafer-Cherif I, Nivoit P, Manriquez V, Tanimoto H, Husson J, Henry N, Chate H, Voituriez R, Dumenil G. 2018. Intermittent Pili-Mediated Forces Fluidize Neisseria meningitidis Aggregates Promoting Vascular Colonization. Cell doi:10.1016/j.cell.2018.04.010.

74. Mairey E, Genovesio A, Donnadieu E, Bernard C, Jaubert F, Pinard E, Seylaz J, Olivo-Marin JC, Nassif X, Dumenil G. 2006. Cerebral microcirculation shear stress levels determine Neisseria meningitidis attachment sites along the blood-brain barrier. J Exp Med 203:1939-1950.

75. Faust SN, Levin M, Harrison OB, Goldin RD, Lockhart MS, Kondaveeti S, Laszik Z, Esmon CT, Heyderman RS. 2001. Dysfunction of endothelial protein $C$ activation in severe meningococcal sepsis. N Engl J Med 345:408416.

76. Imhaus AF, Dumenil G. 2014. The number of Neisseria meningitidis type IV pili determines host cell interaction. EMBO J 33:1767-1783.

77. Bernard SC, Simpson N, Join-Lambert O, Federici C, Laran-Chich MP, Maissa N, Bouzinba-Segard H, Morand PC, Chretien F, Taouji S, Chevet E, Janel S, Lafont F, Coureuil M, Segura A, Niedergang F, Marullo S, Couraud PO, Nassif X, Bourdoulous S. 2014. Pathogenic Neisseria meningitidis utilizes CD147 for vascular colonization. Nat Med 20:725-731.

78. Maissa N, Covarelli V, Janel S, Durel B, Simpson N, Bernard SC, PardoLopez L, Bouzinba-Segard H, Faure C, Scott MGH, Coureuil M, Morand PC, Lafont F, Nassif X, Marullo S, Bourdoulous S. 2017. Strength of Neisseria meningitidis binding to endothelial cells requires highly-ordered CD147/beta2-adrenoceptor clusters assembled by alpha-actinin-4. Nat Commun 8:15764.

79. Eugene E, Hoffmann I, Pujol C, Couraud PO, Bourdoulous S, Nassif X. 2002. Microvilli-like structures are associated with the internalization of virulent capsulated Neisseria meningitidis into vascular endothelial cells. J Cell Sci 115:1231-1241.

80. Soyer M, Charles-Orszag A, Lagache T, Machata S, Imhaus AF, Dumont A, Millien C, Olivo-Marin JC, Dumenil G. 2014. Early sequence of events triggered by the interaction of Neisseria meningitidis with endothelial cells. Cell Microbiol 16:878-895.

81. Mikaty G, Soyer M, Mairey E, Henry N, Dyer D, Forest KT, Morand P, Guadagnini S, Prevost MC, Nassif X, Dumenil G. 2009. Extracellular bacterial pathogen induces host cell surface reorganization to resist shear stress. PLoS Pathog 5:e1000314.

82. Merz AJ, So M. 1997. Attachment of piliated, Opa- and Opc- gonococci and meningococci to epithelial cells elicits cortical actin rearrangements and clustering of tyrosine-phosphorylated proteins. Infect Immun 65:4341-4349.

83. Coureuil M, Mikaty G, Miller F, Lecuyer H, Bernard C, Bourdoulous S, Dumenil G, Mege RM, Weksler BB, Romero IA, Couraud PO, Nassif X. 2009. Meningococcal type IV pili recruit the polarity complex to cross the brain endothelium. Science 325:83-87.

84. Hoen B, Duval X. 2013. Infective endocarditis. N Engl J Med 369:785.

85. Cahill TJ, Prendergast BD. 2016. Infective endocarditis. Lancet 387:882893. 
86. Vilcant V, Hai O. 2018. Endocarditis, Bacterial, StatPearls, Treasure Island (FL).

87. McDonald JR, Olaison L, Anderson DJ, Hoen B, Miro JM, Eykyn S, Abrutyn E, Fowler VG, Jr., Habib G, Selton-Suty C, Pappas PA, Cabell CH, Corey GR, Marco F, Sexton DJ. 2005. Enterococcal endocarditis: 107 cases from the international collaboration on endocarditis merged database. Am J Med 118:759-766.

88. Yew HS, Murdoch DR. 2012. Global trends in infective endocarditis epidemiology. Curr Infect Dis Rep 14:367-372.

89. Widmer E, Que YA, Entenza JM, Moreillon P. 2006. New concepts in the pathophysiology of infective endocarditis. Curr Infect Dis Rep 8:271-279.

90. Hemler ME, Elices MJ, Parker C, Takada Y. 1990. Structure of the integrin VLA-4 and its cell-cell and cell-matrix adhesion functions. Immunol Rev 114:45-65.

91. Foster TJ, Hook M. 1998. Surface protein adhesins of Staphylococcus aureus. Trends Microbiol 6:484-488.

92. Chavakis T, Wiechmann K, Preissner KT, Herrmann M. 2005. Staphylococcus aureus interactions with the endothelium: the role of bacterial "secretable expanded repertoire adhesive molecules" (SERAM) in disturbing host defense systems. Thromb Haemost 94:278-285.

93. Moreillon P, Que YA, Bayer AS. 2002. Pathogenesis of streptococcal and staphylococcal endocarditis. Infect Dis Clin North Am 16:297-318.

94. Werdan K, Dietz S, Loffler B, Niemann S, Bushnaq H, Silber RE, Peters G, Muller-Werdan U. 2014. Mechanisms of infective endocarditis: pathogen-host interaction and risk states. Nat Rev Cardiol 11:35-50.

95. Haslinger-Loffler B, Kahl BC, Grundmeier M, Strangfeld K, Wagner B, Fischer U, Cheung AL, Peters G, Schulze-Osthoff K, Sinha B. 2005. Multiple virulence factors are required for Staphylococcus aureus-induced apoptosis in endothelial cells. Cell Microbiol 7:1087-1097.

96. Brouqui P, Raoult D. 2001. Endocarditis due to rare and fastidious bacteria. Clin Microbiol Rev 14:177-207.

97. Fournier PE, Lelievre H, Eykyn SJ, Mainardi JL, Marrie TJ, Bruneel F, Roure C, Nash J, Clave D, James E, Benoit-Lemercier C, Deforges L, Tissot-Dupont H, Raoult D. 2001. Epidemiologic and clinical characteristics of Bartonella quintana and Bartonella henselae endocarditis: a study of 48 patients. Medicine (Baltimore) 80:245-251.

98. Raoult D, Fournier PE, Vandenesch F, Mainardi JL, Eykyn SJ, Nash J, James E, Benoit-Lemercier C, Marrie TJ. 2003. Outcome and treatment of Bartonella endocarditis. Arch Intern Med 163:226-230.

99. Raoult D, Fournier PE, Drancourt M, Marrie TJ, Etienne J, Cosserat J, Cacoub P, Poinsignon Y, Leclercq P, Sefton AM. 1996. Diagnosis of 22 new cases of Bartonella endocarditis. Ann Intern Med 125:646-652.

100. Dehio C. 2004. Molecular and cellular basis of bartonella pathogenesis. Annu Rev Microbiol 58:365-390.

101. Breitschwerdt EB, Kordick DL. 2000. Bartonella infection in animals: carriership, reservoir potential, pathogenicity, and zoonotic potential for human infection. Clin Microbiol Rev 13:428-438.

102. Chomel BB. 2000. Cat-scratch disease. Rev Sci Tech 19:136-150. 
103. Koehler JE, Tappero JW. 1993. Bacillary angiomatosis and bacillary peliosis in patients infected with human immunodeficiency virus. Clin Infect Dis 17:612-624.

104. Regnery RL, Childs JE, Koehler JE. 1995. Infections associated with Bartonella species in persons infected with human immunodeficiency virus. Clin Infect Dis 21 Suppl 1:S94-98.

105. Kostianovsky M, Greco MA. 1994. Angiogenic process in bacillary angiomatosis. Ultrastruct Pathol 18:349-355.

106. Manders SM. 1996. Bacillary angiomatosis. Clin Dermatol 14:295-299.

107. Dehio C, Meyer M, Berger J, Schwarz H, Lanz C. 1997. Interaction of Bartonella henselae with endothelial cells results in bacterial aggregation on the cell surface and the subsequent engulfment and internalisation of the bacterial aggregate by a unique structure, the invasome. J Cell Sci 110 ( Pt 18):2141-2154.

108. Verma A, Davis GE, Ihler GM. 2000. Infection of human endothelial cells with Bartonella bacilliformis is dependent on Rho and results in activation of Rho. Infect Immun 68:5960-5969.

109. Dramsi S, Cossart P. 1998. Intracellular pathogens and the actin cytoskeleton. Annu Rev Cell Dev Biol 14:137-166.

110. Kirby JE, Nekorchuk DM. 2002. Bartonella-associated endothelial proliferation depends on inhibition of apoptosis. Proc Natl Acad Sci U S A 99:4656-4661.

111. Schulein R, Dehio C. 2002. The VirB/VirD4 type IV secretion system of Bartonella is essential for establishing intraerythrocytic infection. Mol Microbiol 46:1053-1067.

112. Seubert A, Hiestand R, de la Cruz F, Dehio C. 2003. A bacterial conjugation machinery recruited for pathogenesis. Mol Microbiol 49:1253-1266.

113. Torisu H, Ono M, Kiryu H, Furue M, Ohmoto Y, Nakayama J, Nishioka Y, Sone S, Kuwano M. 2000. Macrophage infiltration correlates with tumor stage and angiogenesis in human malignant melanoma: possible involvement of TNFalpha and IL-1alpha. Int $J$ Cancer 85:182-188.

114. Musso T, Badolato R, Ravarino D, Stornello S, Panzanelli P, Merlino C, Savoia D, Cavallo R, Ponzi AN, Zucca M. 2001. Interaction of Bartonella henselae with the murine macrophage cell line J774: infection and proinflammatory response. Infect Immun 69:5974-5980.

115. Kempf VA, Volkmann B, Schaller M, Sander CA, Alitalo K, Riess T, Autenrieth IB. 2001. Evidence of a leading role for VEGF in Bartonella henselae-induced endothelial cell proliferations. Cell Microbiol 3:623-632.

116. Resto-Ruiz SI, Schmiederer M, Sweger D, Newton C, Klein TW, Friedman H, Anderson BE. 2002. Induction of a potential paracrine angiogenic loop between human THP-1 macrophages and human microvascular endothelial cells during Bartonella henselae infection. Infect Immun 70:4564-4570.

117. Minasyan H. 2016. Mechanisms and pathways for the clearance of bacteria from blood circulation in health and disease. Pathophysiology 23:61-66.

118. Khakpour S, Wilhelmsen K, Hellman J. 2015. Vascular endothelial cell Tolllike receptor pathways in sepsis. Innate Immun 21:827-846.

119. Gupta SK, Lysko PG, Pillarisetti K, Ohlstein E, Stadel JM. 1998. Chemokine receptors in human endothelial cells. Functional expression of CXCR4 and its transcriptional regulation by inflammatory cytokines. $J$ Biol Chem 273:4282-4287. 
120. Murdoch C, Monk PN, Finn A. 1999. Cxc chemokine receptor expression on human endothelial cells. Cytokine 11:704-712.

121. Mitchell JA, Ryffel B, Quesniaux VF, Cartwright N, Paul-Clark M. 2007. Role of pattern-recognition receptors in cardiovascular health and disease. Biochem Soc Trans 35:1449-1452.

122. Opitz B, Eitel J, Meixenberger K, Suttorp N. 2009. Role of Toll-like receptors, NOD-like receptors and RIG-l-like receptors in endothelial cells and systemic infections. Thromb Haemost 102:1103-1109.

123. Marceau F, Grassi J, Frobert Y, Bergeron C, Poubelle PE. 1992. Effects of experimental conditions on the production of interleukin-1 alpha and -1 beta by human endothelial cells cultured in vitro. Int $\mathrm{J}$ Immunopharmacol 14:525-534.

124. Opitz B, Puschel A, Beermann W, Hocke AC, Forster S, Schmeck B, van Laak V, Chakraborty T, Suttorp N, Hippenstiel S. 2006. Listeria monocytogenes activated p38 MAPK and induced IL-8 secretion in a nucleotide-binding oligomerization domain 1-dependent manner in endothelial cells. J Immunol 176:484-490.

125. Anand AR, Cucchiarini M, Terwilliger EF, Ganju RK. 2008. The tyrosine kinase Pyk2 mediates lipopolysaccharide-induced IL-8 expression in human endothelial cells. J Immunol 180:5636-5644.

126. Faure E, Thomas L, Xu H, Medvedev A, Equils O, Arditi M. 2001. Bacterial lipopolysaccharide and IFN-gamma induce Toll-like receptor 2 and Toll-like receptor 4 expression in human endothelial cells: role of NF-kappa B activation. J Immunol 166:2018-2024.

127. Danese S, Dejana E, Fiocchi C. 2007. Immune regulation by microvascular endothelial cells: directing innate and adaptive immunity, coagulation, and inflammation. J Immunol 178:6017-6022.

128. Neefjes J, Jongsma ML, Paul P, Bakke O. 2011. Towards a systems understanding of $\mathrm{MHC}$ class I and $\mathrm{MHC}$ class II antigen presentation. Nat Rev Immunol 11:823-836.

129. Rose ML, Coles MI, Griffin RJ, Pomerance A, Yacoub MH. 1986. Expression of class I and class II major histocompatibility antigens in normal and transplanted human heart. Transplantation 41:776-780.

130. Leeuwenberg JF, Van Damme J, Meager T, Jeunhomme TM, Buurman WA. 1988. Effects of tumor necrosis factor on the interferon-gamma-induced major histocompatibility complex class II antigen expression by human endothelial cells. Eur J Immunol 18:1469-1472.

131. Mai J, Virtue A, Shen J, Wang H, Yang XF. 2013. An evolving new paradigm: endothelial cells--conditional innate immune cells. J Hematol Oncol 6:61.

132. van der Poll T, van de Veerdonk FL, Scicluna BP, Netea MG. 2017. The immunopathology of sepsis and potential therapeutic targets. Nat Rev Immunol 17:407-420.

133. Wiersinga WJ, Leopold SJ, Cranendonk DR, van der Poll T. 2014. Host innate immune responses to sepsis. Virulence 5:36-44.

134. Levy MM, Fink MP, Marshall JC, Abraham E, Angus D, Cook D, Cohen J, Opal SM, Vincent JL, Ramsay G, Sccm/Esicm/Accp/Ats/Sis. 2003. 2001 SCCM/ESICM/ACCPIATS/SIS International Sepsis Definitions Conference. Crit Care Med 31:1250-1256.

135. Rittirsch D, Flierl MA, Ward PA. 2008. Harmful molecular mechanisms in sepsis. Nat Rev Immunol 8:776-787. 
136. Hotchkiss RS, Moldawer LL, Opal SM, Reinhart K, Turnbull IR, Vincent JL. 2016. Sepsis and septic shock. Nat Rev Dis Primers 2:16045.

137. Hotchkiss RS, Tinsley KW, Swanson PE, Grayson MH, Osborne DF, Wagner TH, Cobb JP, Coopersmith C, Karl IE. 2002. Depletion of dendritic cells, but not macrophages, in patients with sepsis. J Immunol 168:2493-2500.

138. Hotchkiss RS, Monneret G, Payen D. 2013. Sepsis-induced immunosuppression: from cellular dysfunctions to immunotherapy. Nat Rev Immunol 13:862-874.

139. Scumpia PO, Delano MJ, Kelly-Scumpia KM, Weinstein JS, Wynn JL, Winfield RD, Xia C, Chung CS, Ayala A, Atkinson MA, Reeves WH, ClareSalzler MJ, Moldawer LL. 2007. Treatment with GITR agonistic antibody corrects adaptive immune dysfunction in sepsis. Blood 110:3673-3681.

140. Boomer JS, To K, Chang KC, Takasu O, Osborne DF, Walton AH, Bricker TL, Jarman SD, 2nd, Kreisel D, Krupnick AS, Srivastava A, Swanson PE, Green JM, Hotchkiss RS. 2011. Immunosuppression in patients who die of sepsis and multiple organ failure. JAMA 306:2594-2605.

141. Huang X, Venet F, Wang YL, Lepape A, Yuan Z, Chen Y, Swan R, Kherouf H, Monneret G, Chung CS, Ayala A. 2009. PD-1 expression by macrophages plays a pathologic role in altering microbial clearance and the innate inflammatory response to sepsis. Proc Natl Acad Sci U S A 106:63036308.

142. Levi M, Ten Cate H. 1999. Disseminated intravascular coagulation. N Engl J Med 341:586-592.

143. Davis RP, Miller-Dorey S, Jenne CN. 2016. Platelets and coagulation in infection. Clin Transl Immunology 5:e89.

144. Pernerstorfer T, Stohlawetz P, Hollenstein U, Dzirlo L, Eichler HG, Kapiotis S, Jilma B, Speiser W. 1999. Endotoxin-induced activation of the coagulation cascade in humans: effect of acetylsalicylic acid and acetaminophen. Arterioscler Thromb Vasc Biol 19:2517-2523.

145. Osterud B, Bjorklid E. 2001. The tissue factor pathway in disseminated intravascular coagulation. Semin Thromb Hemost 27:605-617.

146. Abraham E. 2000. Coagulation abnormalities in acute lung injury and sepsis. Am J Respir Cell Mol Biol 22:401-404.

147. Ince C. 2005. The microcirculation is the motor of sepsis. Crit Care $\mathbf{9}$ Suppl 4:S13-19. 


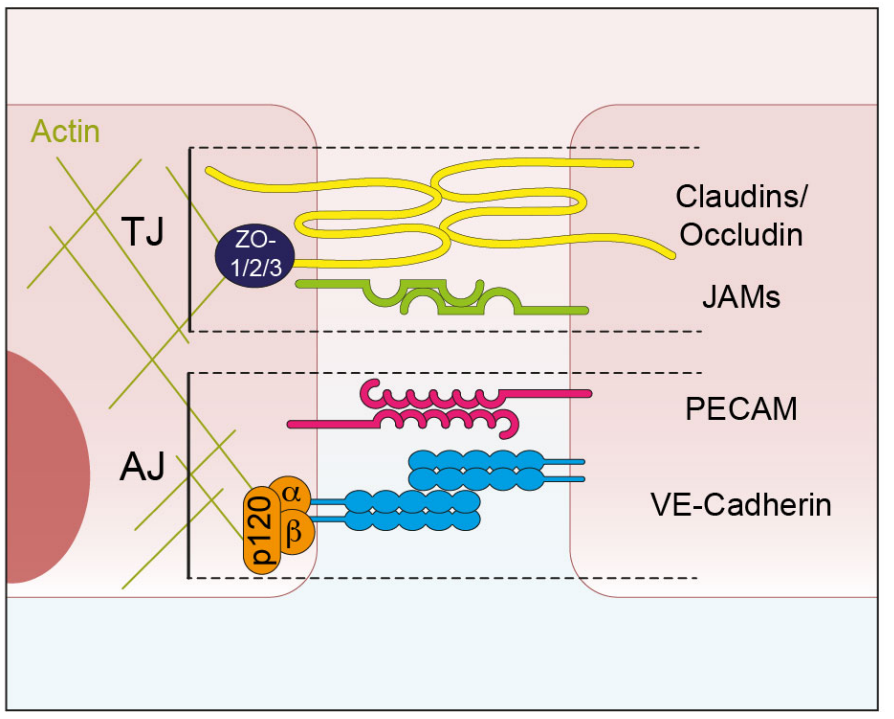

831 Figure 1: Schematic representation of the two main types of intercellular

832 junctions within the endothelium. Adherens junctions (AJ) are made by the 833 homophilic interaction of Vascular Endothelial (VE)-Cadherin and PECAM (Platelet 834 endothelial cell adhesion molecule, also known as CD31). In contrast, claudins, 835 occludin and proteins from the junctional adhesion molecules (JAMs) family are 836 involved in establishing tight junctions. Connection with the actin cytoskeleton is 837 ensured by proteins of the catenin family (alpha-, beta- and p120-catenin) in the case 838 of adherens junctions, and proteins from the zonula occludens family (ZO-1, -2 and 839 3) in the case of tight junctions. 


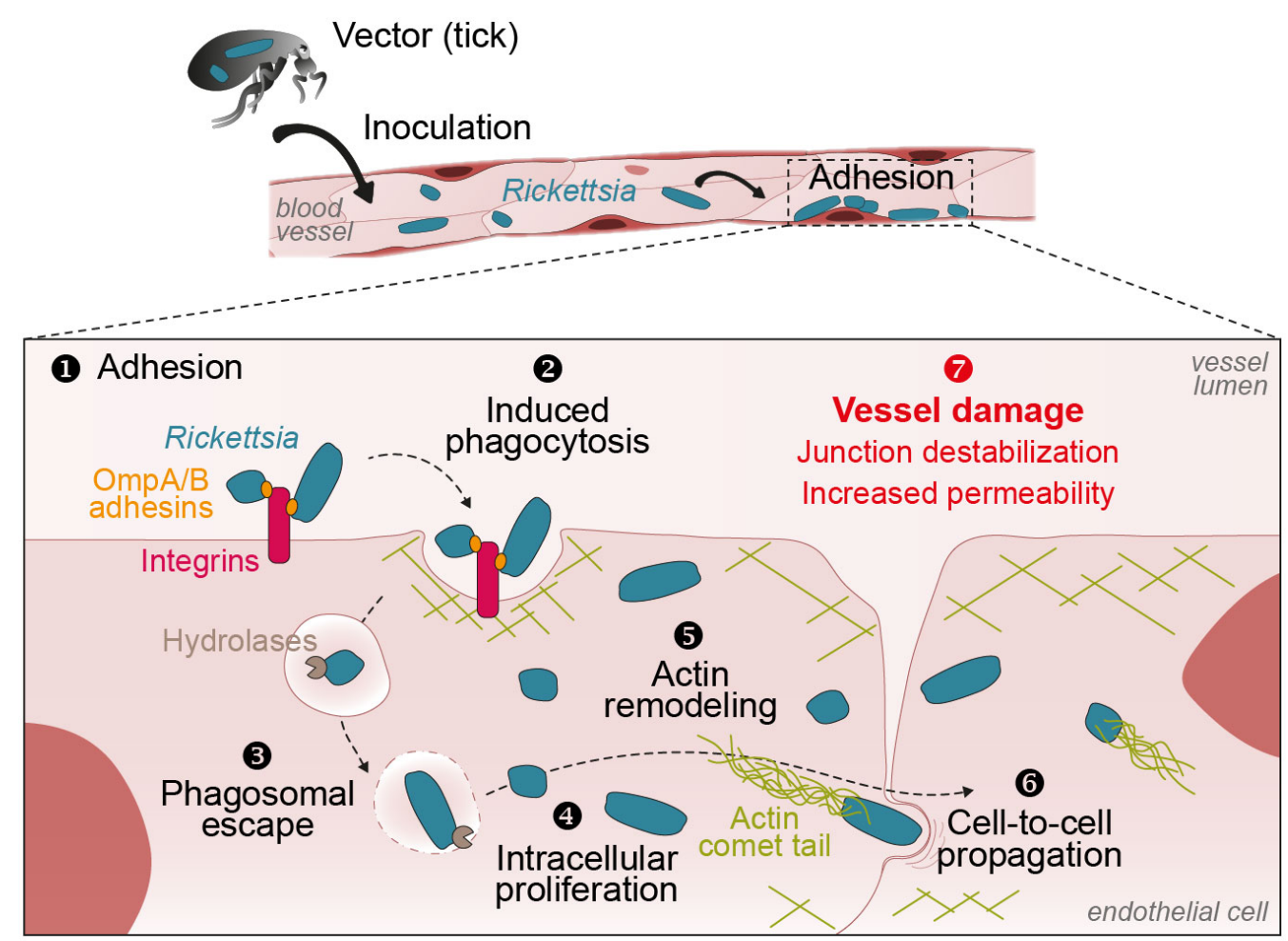

841

842 Figure 2: Infection of the endothelium by Rickettsia. Following bacterial

843 inoculation into the lumen of blood vessels, Rickettsia adheres at the surface of the

844 endothelium through the surface expression of the outer-membrane protein (Omp)-A

845 and $-B$. Binding of Omp-A/B to cell-surface integrins induces the phagocytosis of

846 bacteria and the remodeling of the cellular actin cytoskeleton. Then, Hemolysin C

847 and/or Phospholipase D-expressing bacteria escape phagosomal vesicles, proliferate

848 intracellularly and utilize cellular components, such as actin monomers and nutrients,

849 to assemble actin comet tails supporting bacterial movement and cell-to-cell

850 spreading. Both actin cytoskeleton remodeling and bacterial propagation participate

851 in damaging infected vessels, including the destabilization of cellular junctions

852 responsible for the increase in vessel permeability. 


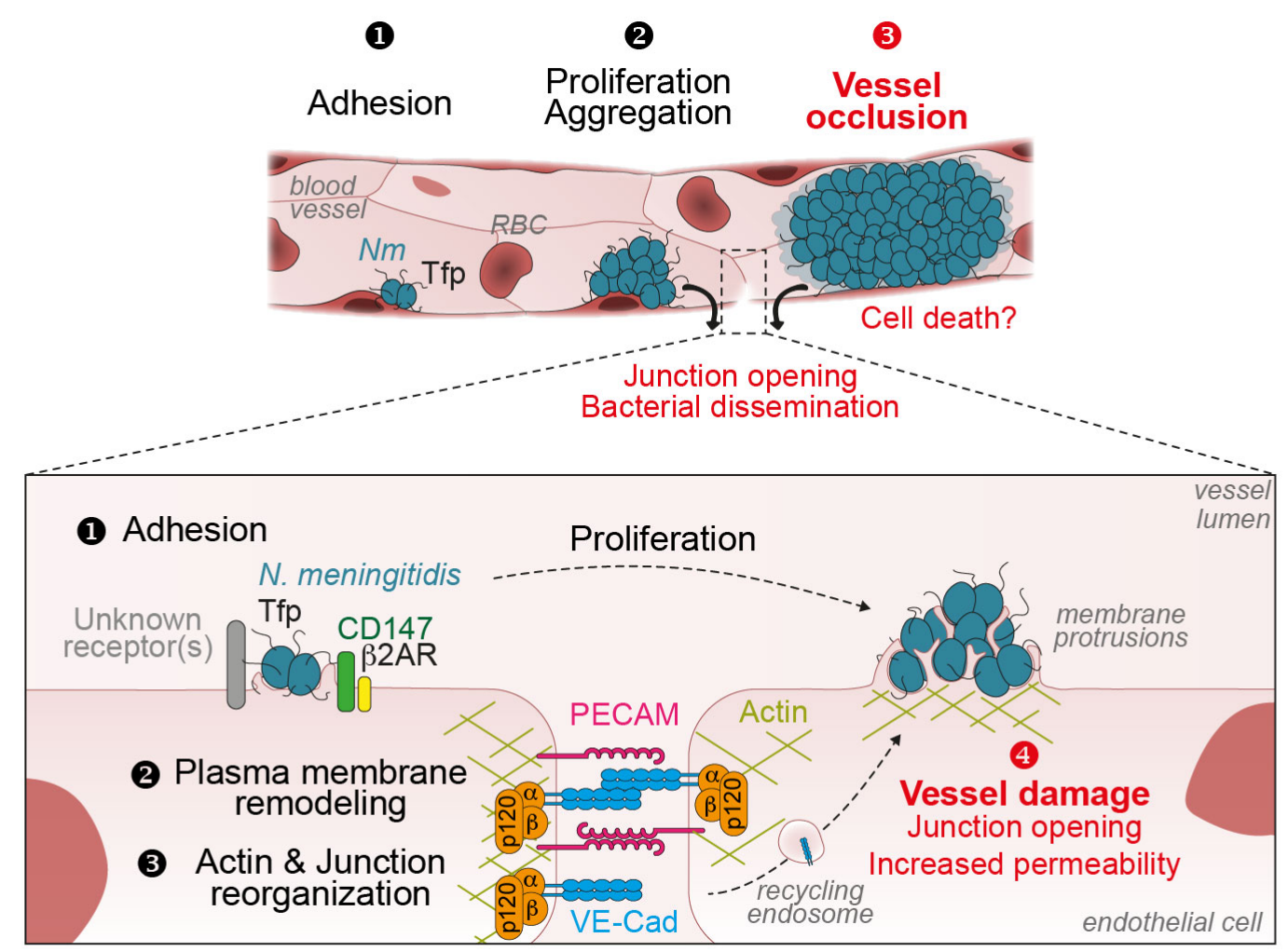

854

855 Figure 3: Vascular colonization by Neisseria meningitidis. Once into the 856 bloodstream, Neisseria meningitidis adheres to the endothelium thanks to the surface 857 expression of type four pili (Tfp). While proliferating, and owing to their auto858 aggregative property, bacteria form a tight microcolony at the surface of the 859 endothelium, which ultimately leads to the congestion of the colonized vessel. 860 Bacterial adhesion at the surface of endothelial cells induces a drastic remodeling of 861 the host cell-plasma membrane that forms membrane protrusions interdigitating 862 within the bacterial aggregate. In addition, pilus interaction with endothelial cell863 surface receptors, such as CD147 or $\beta 2$-adrenergic receptor ( $\beta 2-A R)$, induces the 864 reorganization of the actin cytoskeleton and intercellular junctions by recruiting their components underneath the microcolony. Taken together, these events are proposed 866 to destabilize intercellular junctions, hence resulting in the increase in vessel 867 permeability. 


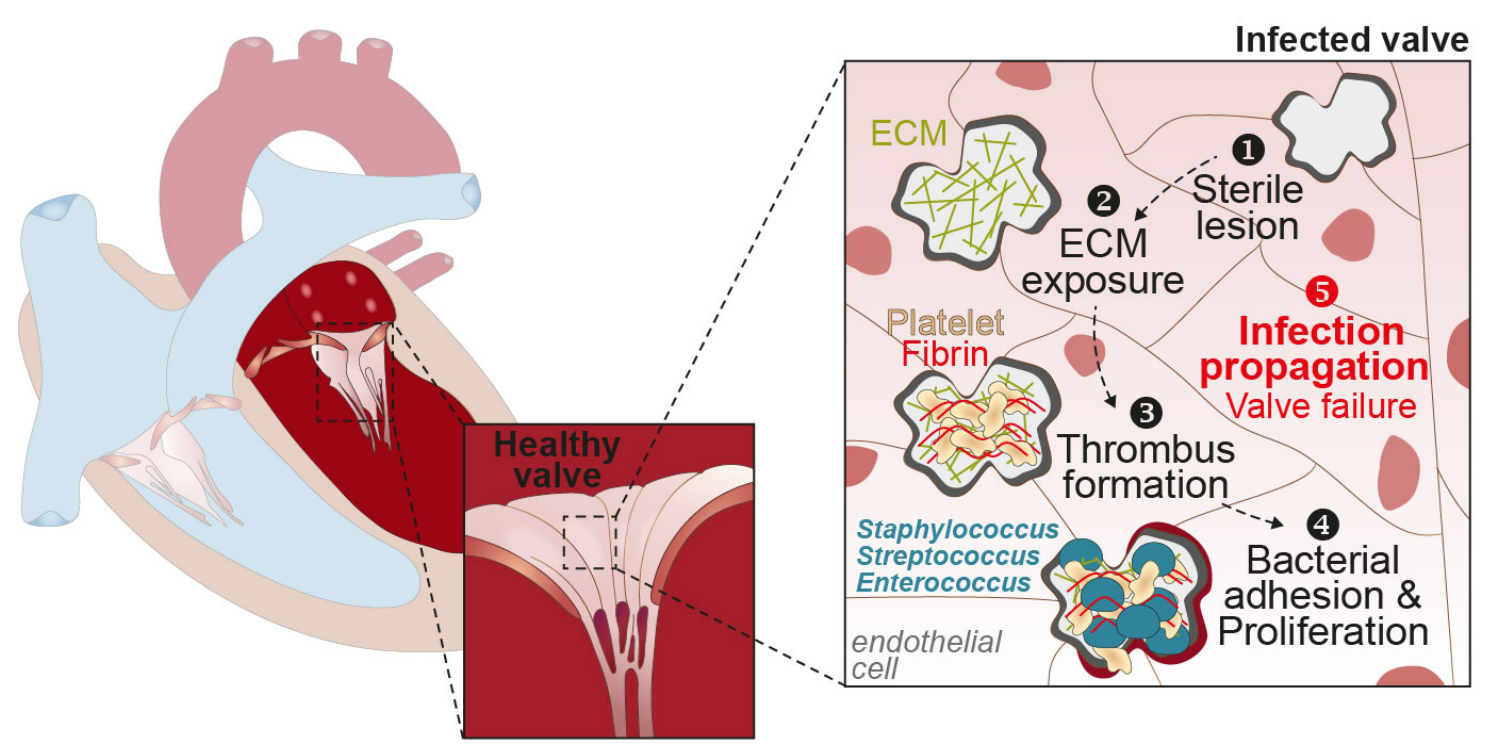

869

870 Figure 4: The stepwise process leading to endocarditis. The apparition of sterile

871 lesions (most often of unknown origin) on the heart valvular endothelium leads to the 872 exposure of the underneath extracellular matrix (ECM). This in turn triggers the

873 formation of a thrombus - characterized by the local deposition of platelets and fibrin

874 at the surface of the damaged endothelium - that favors bacterial adhesion. While

875 bacteria proliferate and spread, the valvular endothelium become more and more 876 damaged, eventually leading to the failure of the valve and the need for its surgical 877 replacement.

878 


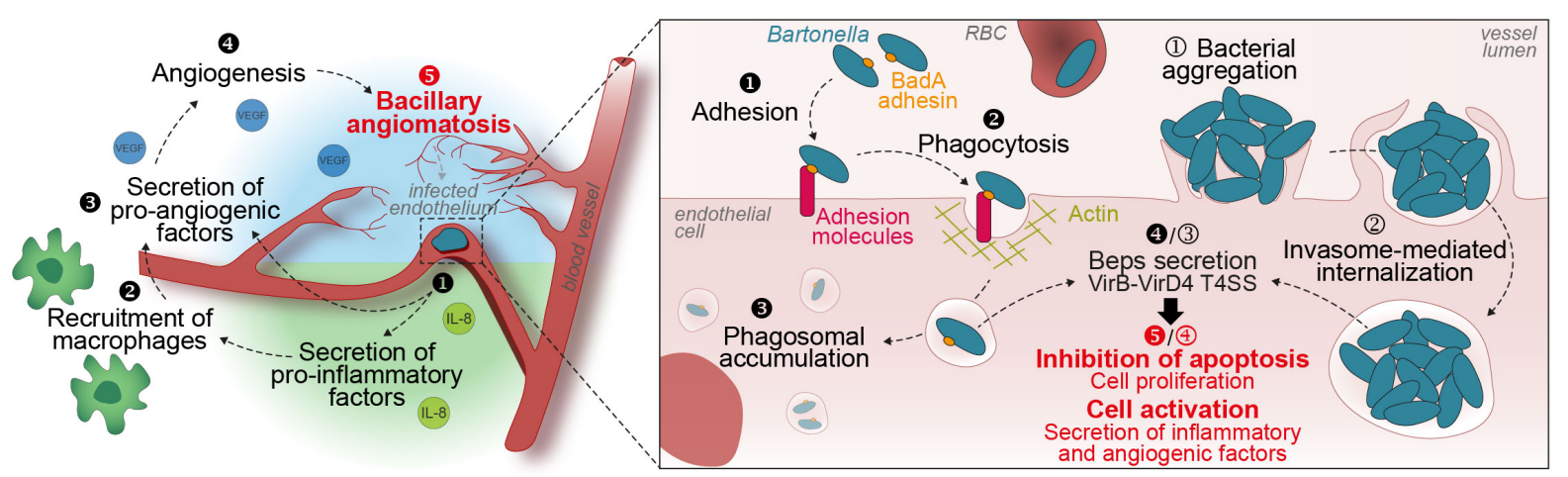

879

880 Figure 5: Bartonella-induced angioproliferation. Interactions of Bartonella with the 881 endothelium might occur at the single-bacterium level through the bacterial expression of the Bartonella adhesin A (BadA) protein. This triggers the phagocytosis of the cell-surface bound bacteria and results in their perinuclear accumulation within 884 phagosomes. Similarly, to Neisseria meningitidis, Bartonella also forms aggregates 885 that are internalized through a slower process within big vacuoles, referred to as 886 invasomes. In both cases, the VirB-VirD4 type four secretion system (T4SS)887 dependent cytoplasmic release of Bartonella effector proteins (Beps) by intra888 vesicular bacteria promotes the proliferation and activation of the infected endothelial 889 cells. This notably results in the secretion by the endothelium of pro-inflammatory 890 (e.g. IL-8) and pro-angiogenic (e.g. VEGF) factors. As a consequence, cells from the 891 innate immunity, including neutrophils and macrophages, are locally recruited to fight 892 the infection. Activated macrophages locally secrete VEGF, thus reinforcing the pro893 angiogenic microenvironment. Combined to the bacterium-mediated endothelial cell 894 proliferation, this particular environment promotes angiogenesis that ultimately leads 895 to the local accumulation of new blood capillaries and the formation of Bacillary 896 Angiomatosis lesions. 